\title{
Could Uric acid have a Pathogenic Role in Chronic Allograft Dysfunction?
}

\author{
Marilda Mazzali $^{\mathrm{a}^{*}}$, Rasha Kazamel ${ }^{\mathrm{b}}$, Richard J Johnson ${ }^{\mathrm{c}}$ \\ a. Division of Nephrology, Universidade Estadual de Campinas, UNICAMP, Campinas-SP, Brazil \\ b. Medical School, Cairo University, Egypt \\ c. University of Colorado Health Sciences Center, Denver, Colorado, USA
}

\begin{abstract}
Introduction: Chronic allograft dysfunction (CAD) is the primary cause of chronic graft failure after kidney transplantation. The pathogenesis of CAD involves both antigen-dependent and antigen-independent mechanisms. Serum uric acid could have a role in both mechanisms.
\end{abstract}

Review: Hyperuricemia in subjects with renal transplantation is not usually viewed as clinically significant unless the subject develops gout. Drugs used in the treatment of hyperuricemia and gout are more likely to cause side effects in the kidney transplant reciepient. However, there are recent studies that raise the possibility that uric acid could have a role in CAD. Soluble uric acid has been shown to stimulate the proliferation of vascular smooth muscle, to inhibit endothelial cell proliferation and to reduce bioactive levels of endothelial NO. Studies in experimental models have found that hyperuricemia can cause hypertension associated with renal injury characterized by microvascular disease, tubulointerstitial disease, glomerular hypertrophy and glomerulosclerosis. Hyperuricemia was also found to worsen preexistent renal disease, and to be associated with the development of severe vascular lesions that are reminiscent of those observed in CAD. Furthermore, chronic cyclosporine nephropathy is very similar to what is observed in normal rats simply by raising uric acid levels. In addition, raising uric acid levels in rats receiving cyclosporine accelerates the nephropathy whereas lowering uric acid ameliorates the renal lesions.

Conclusion: The pathogenic role of uric acid in CAD is still controversial. A controlled clinical trial would be the best approach to determine the effect of uric acid lowering treatment on the development of CAD and long term graft function.

\footnotetext{
* Corresponding author; Division of Nephrology, Universidade Estadual de Campinas, UNICAMP, Campinas-SP, Brazil.

E mail: mazzma@uol.com.br
}

Keywords: chronic allograft dysfunction, cyclosporine, uric acid, hyperuricemia, vascular disease

\section{Introduction}

Chronic allograft dysfunction (CAD) refers to progressive dysfunction of an allograft renal transplant, with biopsy findings of tubular atrophy, interstitial fibrosis, progressive glomerulosclerosis and variable degrees of arterial/fibrointimal thickening or arteriolar hyalinosis $[1,2]$. CAD remains the primary cause of chronic graft failure after renal transplantation and increases the risk for cardiovascular mortality in this group of patients. Understanding the cause(s) of CAD and potential treatments remains a major goal in transplantation [1].

Most studies suggest that the pathogenesis of CAD involves both antigen-dependent and antigen-independent mechanisms [3]. Antigen-dependent (immune mediated) $\mathrm{CAD}$, such as observed with chronic allograft rejection, is often associated with a previous history of acute or subclinical rejection, lower HLA matching, the presence of higher panel reactive antibodies (PRA), and in some instances the detection or development of donor specific antibodies (DSA). In contrast, antigen-independent CAD is often associated with the use of calcineurin inhibitors (CNI), a history of delayed graft function, the presence of classical cardiovascular risk factors (such as hypertension and dyslipidemia) and proteinuria. The differential diagnosis of antigen-independent CAD includes hypertension-associated vascular injury, viral infection, chronic obstruction, and chronic pyelonephritis [2].

One factor that could have a role in both antigendependent and antigen-independent CAD is serum uric acid. Uric acid is an end-product of purine metabolism that is excreted primarily by the kidney with a lesser excretion by the gastrointestinal tract. Serum uric acid levels are frequently elevated in subjects following renal transplantation $[4,5]$. A variety of mechanisms may account for the presence of a higher uric acid in transplant recipients, including the effect of calcineurin inhibitors (especially cyclosporine) to reduce urinary net 
urate excretion. Uric acid levels will also increase as the glomerular filtration rate (GFR) falls $[4,6,7]$. In the following section, we review the potential pathogenic role of uric acid in chronic renal allograft dysfunction.

\section{Review}

Originally the increase in serum uric acid in subjects with renal transplantation was not viewed as clinically significant unless a subject developed gout. Several studies have discussed the problems with treatment of gout in the renal transplant patient [8]. For example, colchicine can occasionally precipitate a myopathy in transplant recipients, nonsteroidal agents can cause deterioration in renal function, and probenecid is often ineffective in the setting of reduced renal function. Allopurinol is relatively contraindicated in subjects receiving azathioprine as it may augment its toxicity to cause leucopenia. Importantly mycophenolate mofetil does not have this interaction with allopurinol [9]. The dose of allopurinol also needs to be adjusted in the setting of reduced renal function because of the risk for a Stevens Johnson-like syndrome or allopurinol nephrotoxicity. Benziodarone and benzbromarone may be effective at lowering uric acid levels in the setting of impaired renal function but these agents are not available in many parts of the world, and benzbromarone may also cause hepatotoxicity [9]. Thus, treatment of hyperuricemia in the transplant recipient is often aimed at reducing the dose of calcineurin inhibitors, using CNI sparing protocols or administering low doses of allopurinol [10].

While hyperuricemia has usually only concerned the transplant nephrologist if the subject develops gout, there are recent studies that raise the possibility that uric acid could have a role in CAD $[11,12]$. First, there is increasing experimental evidence that chronic hyperuricemia may have effects on vascular cells that may predispose to chronic vascular disease such as observed in subjects with chronic allograft nephropathy. For example, soluble uric acid has been shown to potently activate and stimulate the proliferation of vascular smooth muscle cells [13]. The mechanism involves uptake via specific organic anion transporters, such as URAT1, with the activation of mitogen activated protein kinases (p38 and ERK) and nuclear transcription factors $(\mathrm{NF}-\mathrm{KB})$ with the production of platelet-derived growth factor cyclooxygenase-2 mediated thromboxane, inflammatory proteins (monocyte chemoattractant protein-1 and C-reactive protein) and vasoactive mediators (oxidants and angiotensin II) [14-20]. Soluble uric acid has also been found to inhibit endothelial cell proliferation and migration in vitro and to reduce bioactive levels of endothelial $\mathrm{NO}$, the latter via several mechanism including direct scavenging of NO and the stimulation of arginase [18, 21, 22]. Uric acid has also been shown to have a variety of direct effects on tubular epithelial cells as well as on neutrophils and monocytes [23, 24].

Consistent with the in vitro studies, studies in experimental models have found that hyperuricemia can cause hypertension associated with renal injury characterized by microvascular disease, tubulointerstitial disease, and glomerular hypertrophy and glomerulosclerosis $[17,25$, 26]. Hyperuricemia was also found to worsen preexistent renal disease, and to be associated with the development of severe vascular lesions that are reminiscent of those observed in chronic allograft nephropathy [27]. Other studies also suggest that uric acid may have a role in inducing features of the metabolic syndrome, including insulin resistance and dyslipidemia [28]. Fewer clinical studies are available, but there is also accruing evidence that uric acid may have a role in some forms of hypertension and chronic kidney disease [29, 30].

Experimental studies also suggest that uric acid could have a role in chronic calcineurin toxicity. Chronic cyclosporine use, and to a lesser extent, tacrolimus, are associated with the development of hyperuricemia, renal vasoconstriction, hypertension and a renal lesion characterized by afferent arteriolar hyalinosis and tubulointerstitial fibrosis. Interestingly, the administration of allopurinol (a xanthine-oxidase inhibitor which lowers uric acid) to rats can attenuate both the renal vasoconstriction and the decrease in glomerular filtration rate induced by cyclosporine [31, 32]. Furthermore, chronic cyclosporine nephropathy is very similar to what has been observed in normal rats simply by raising uric acid levels [26]. In addition, raising uric acid levels in rats receiving cyclosporine accelerates the nephropathy whereas lowering uric acid ameliorates the renal lesions [33]. Whether lowering uric acid can improve cyclosporine nephropathy in humans is unknown. However, a pilot study did report that lowering uric acid with allopurinol was associated with an improvement in renal function in hyperuricemic liver transplant recipients [34].

While these studies implicate uric acid as a potential risk factor for antigen-independent $\mathrm{CAD}$, there may also be a potential role for uric acid in antigen-dependent CAD. Recently Shi et al found that uric acid has a critical role in the activation of dendritic cells to host antigens, particularly in conditions associated with chronic tissue injury [35]. The same group later showed that uric acid participates in the activation of CD8 T cells to transplanted cells [36]. More recent studies have shown that uric acid can directly activate $T$ cells [37] and enhances the T cell responses to dendritic cell-based vaccines [38]. Uric acid also potentiates B cell immune responses [39], and can activate the IL-1 receptor on monocytes via a Toll 
receptor pathway involving MyD88-dependent signaling [40]. Allopurinol has also been shown to reduce immune responses to antigens in normal mice [41]. Moreover, one clinical report suggested that the addition of allopurinol translated into less rejection in renal transplant recipients [42].

Studies in man suggest that uric acid may be a predictor for reduced renal function [12], cyclosporine nephrotoxicity [43], and CAD associated with renal transplantation [44]. Uric acid has also been associated with allograft vasculopathy in cardiac transplant recipients [45]. Nevertheless, there are also studies that have not been able to show a relationship between uric acid and long term renal outcomes [46]. However, it may be difficult to show the epidemiological association of uric acid with progressive renal insufficiency since uric acid itself is also altered by the degree of underlying renal function. Hence, the best approach to determining the effect of uric acid on CAD and long term renal outcome will require a controlled clinical trial in which uric acid levels are actively lowered. Given the potential toxicities with current uric acid-lowering therapies, this may not be an easy task. However, there are newer agents on the horizon that may be useful for this purpose, including the xanthine-oxidase inhibitor, febuxostat, in which dosing is not affected by renal function and in which serious allergic reactions are rare. Until then, the possibility that uric acid has a pathogenic role in CAD must remain conjectural.

\section{Conclusion}

The pathogenic role of uric acid in CAD is still controversial. However, there are several reports in the literature suggesting that hyperuricemia is a contributing factor to the development of CAD. A controlled clinical trial would be the best approach to determine the effect of uric acid lowering treatment on the development of CAD and long term graft function.

\section{References}

1. Jevnikar AM, Mannon RB. Late kidney allograft loss: what we know about it, and what we can do about it. Clin J Am Soc Nephrol. 2008;3 Suppl 2:S56-67.

2. Solez K, Colvin RB, Racusen LC, Sis B, Halloran PF, Birk PE, Campbell PM, Cascalho M, Collins AB, Demetris AJ, Drachenberg CB, Gibson IW, Grimm PC, Haas M, Lerut E, Liapis H, Mannon RB, Marcus PB, Mengel M, Mihatsch MJ, Nankivell BJ, Nickeleit V, Papadimitriou JC, Platt JL, Randhawa P, Roberts I, Salinas-Madriga L, Salomon DR, Seron D, Sheaff M, Weening JJ. Banff05 Meeting Report: differential diagnosis of chronic allograft injury and elimination of chronic allograft nephropathy ('CAN'). Am J Transplant. 2007;7(3):518-26.

3. Najafian B, Kasiske BL. Chronic allograft nephropathy. Curr Opin Nephrol Hypertens. 2008;17(2):149-55.

4. Mazzali M. Uric acid and transplantation. Semin Nephrol. 2005;25(1):50-5.

5. Perico N, Codreanu I, Caruso M, Remuzzi G. Hyperuricemia in kidney transplantation. Contrib Nephrol. 2005;147:124-31.

6. Kanbay M, Akcay A, Huddam B, Usluogullari CA, Arat Z, Ozdemir FN, Haberal M. Influence of cyclosporine and tacrolimus on serum uric acid levels in stable kidney transplant recipients. Transplant Proc. 2005;37(7):311920.

7. Laine J, Holmberg C. Mechanisms of hyperuricemia in cyclosporine-treated renal transplanted children. Nephron. 1996;74(2):318-23.

8. Abbott KC, Kimmel PL, Dharnidharka V, Oglesby RJ, Agodoa LY, Caillard S. New-onset gout after kidney transplantation: incidence, risk factors and implications. Transplantation. 2005;80(10):1383-1391.

9. Stamp L, Searle M, O'Donnell J, Chapman P. Gout in solid organ transplantation: a challenging clinical problem. Drugs. 2005;65(18):2593-611.

10. Perez-Ruiz F, Gomez-Ullate P, Amenabar JJ, Zarraga S, Calabozo M, Herrero-Beites AM, Nolla JM. Long-term efficacy of hyperuricaemia treatment in renal transplant patients. Nephrol Dial Transplant. 2003;18(3):603-6.

11. Akgul A, Bilgic A, Ibis A, Ozdemir FN, Arat Z, Haberal M. Is uric acid a predictive factor for graft dysfunction in renal transplant recipients? Transplant Proc. 2007;39(4):1023-6.

12. Armstrong KA, Johnson DW, Campbell SB, Isbel NM, Hawley CM. Does uric acid have a pathogenetic role in graft dysfunction and hypertension in renal transplant recipients? Transplantation. 2005;80(11):1565-71.

13. Rao GN, Corson MA, Berk BC. Uric acid stimulates vascular smooth muscle cell proliferation by increasing platelet-derived growth factor A-chain expression. J Biol Chem. 1991;266(13):8604-8.

14. Price KL, Sautin YY, Long DA, Zhang L, Miyazaki $\mathrm{H}, \mathrm{Mu} \mathrm{W}$, Endou H, Johnson RJ. Human vascular smooth muscle cells express a urate transporter. J Am Soc Nephrol. 2006;17(7):1791-5.

15. Kang DH, Han L, Ouyang X, Kahn AM, Kanellis J, Li P, Feng L, Nakagawa T, Watanabe S, Hosoyamada M, Endou H, Lipkowitz M, Abramson R, Mu W, Johnson RJ. 
Uric acid causes vascular smooth muscle cell proliferation by entering cells via a functional urate transporter. Am J Nephrol. 2005;25(5):425-33.

16. Kanellis J, Watanabe S, Li JH, Kang DH, Li P, Nakagawa T, Wamsley A, Sheikh-Hamad D, Lan HY, Feng L, Johnson RJ. Uric acid stimulates monocyte chemoattractant protein-1 production in vascular smooth muscle cells via mitogen-activated protein kinase and cyclooxygenase-2. Hypertension. 2003;41(6):1287-93.

17. Mazzali M, Kanellis J, Han L, Feng L, Xia YY, Chen Q, Kang DH, Gordon KL, Watanabe S, Nakagawa T, Lan HY, Johnson RJ. Hyperuricemia induces a primary renal arteriolopathy in rats by a blood pressureindependent mechanism. Am J Physiol Renal Physiol. 2002;282(6):F991-7.

18. Kang DH, Park SK, Lee IK, Johnson RJ. Uric acidinduced C-reactive protein expression: implication on cell proliferation and nitric oxide production of human vascular cells. J Am Soc Nephrol. 2005;16(12):3553-62.

19. Corry DB, Eslami P, Yamamoto K, Nyby MD, Makino H, Tuck ML. Uric acid stimulates vascular smooth muscle cell proliferation and oxidative stress via the vascular renin-angiotensin system. J Hypertens. 2008;26(2):269-75

20. Watanabe S, Kang DH, Feng L, Nakagawa T, Kanellis J, Lan H, Mazzali M, Johnson RJ. Uric acid, hominoid evolution, and the pathogenesis of salt-sensitivity. Hypertension. 2002;40(3):355--60.

21. Gersch C, Palii SP, Kim KM, Angerhofer A, Johnson RJ, Henderson GN. Inactivation of nitric oxide by uric acid. Nucleosides Nucleotides Nucleic Acids. 2008;27(8):967-78.

22. Zharikov S, Krotova K, Hu H, Baylis C, Johnson RJ, Block ER, Patel J. Uric acid decreases NO production and increases arginase activity in cultured pulmonary artery endothelial cells. Am J Physiol Cell Physiol. 2008;295(5):C1183-90.

23. Zare F, Magnusson M, Bergstrom T, Brisslert M, Josefsson E, Karlsson A, Tarkowski A. Uric acid, a nucleic acid degradation product, down-regulates dsRNAtriggered arthritis. J Leukoc Biol. 2006;79(3):482-8.

24. Cirillo P, Gersch MS, Mu W, Scherer PM, Gesualdo L, Henderson GN, Johnson RJ, Sautin YY. Ketohexokinase-dependent metabolism of fructose induces proinflammatory mediators in proximal tubular cells. J Am Soc Nephrol. 2009;20(3):545-53.

25. Nakagawa T, Mazzali M, Kang DH, Kanellis J, Watanabe S, Sanchez-Lozada LG, Rodriguez-Iturbe B, Herrera-Acosta J, Johnson RJ. Hyperuricemia causes glomerular hypertrophy in the rat. Am J Nephrol. 2003;23(1):2-7.

26. Mazzali M, Hughes J, Kim YG, Jefferson JA, Kang DH, Gordon KL, Lan HY, Kivlighn S, Johnson RJ. Elevated uric acid increases blood pressure in the rat by a novel crystal-independent mechanism. Hypertension. 2001;38(5):1101-6.

27. Kang DH, Nakagawa T, Feng L, Watanabe S, Han L, Mazzali M, Truong L, Harris R, Johnson RJ. A role for uric acid in the progression of renal disease. J Am Soc Nephrol. 2002;13(12):2888-97.

28. Nakagawa T, Hu H, Zharikov S, Tuttle KR, Short RA, Glushakova O, Ouyang X, Feig DI, Block ER, Herrera-Acosta J, Patel JM, Johnson RJ. A causal role for uric acid in fructose-induced metabolic syndrome. Am J Physiol Renal Physiol. 2006;290(3):F625-31.

29. Siu YP, Leung KT, Tong MK, Kwan TH. Use of allopurinol in slowing the progression of renal disease through its ability to lower serum uric acid level. Am J Kidney Dis. 2006;47(1):51-9.

30. Feig DI, Soletsky B, Johnson RJ. Effect of Allopurinol on the blood pressure of adolescents with newly diagnosed essential hypertension. JAMA. 2008;300(8):924-32.

31. Assis SM, Monteiro JL, Seguro AC. L-Arginine and allopurinol protect against cyclosporine nephrotoxicity. Transplantation. 1997;63(8):1070-3.

32. Kobelt V, Hess T, Matzkies F, Gerhardt U, Hillebrand U, Suwelack B, Sindermann J, Hohage H. Does allopurinol prevent side effects of cyclosporine-A treatment? Transplant Proc. 2002;34(5):1425-7.

33. Mazzali M, Kim YG, Suga S, Gordon KL, Kang DH, Jefferson JA, Hughes J, Kivlighn SD, Lan HY, Johnson RJ. Hyperuricemia exacerbates chronic cyclosporine nephropathy. Transplantation. 2001;71(7):900-5.

34. Neal DA, Tom BD, Gimson AE, Gibbs P, Alexander GJ. Hyperuricemia, gout, and renal function after liver transplantation. Transplantation. 2001;72(10):1689-91.

35. Shi Y, Evans JE, Rock KL. Molecular identification of a danger signal that alerts the immune system to dying cells. Nature. 2003;425(6957):516-21.

36. Shi Y, Galusha SA, Rock KL. Cutting edge: elimination of an endogenous adjuvant reduces the activation of CD8 $\mathrm{T}$ lymphocytes to transplanted cells and in an autoimmune diabetes model. J Immunol. 2006;176(7):3905-8.

37. Webb R, Jeffries M, Sawalha AH. Uric acid directly promotes human T-cell activation. Am J Med Sci. 2009;337(1):23-7. 
38. Ma XJ, Tian DY, Xu D, Yang DF, Zhu HF, Liang ZH, Zhang ZG. Uric acid enhances $\mathrm{T}$ cell immune responses to hepatitis B surface antigen-pulsed-dendritic cells in mice. World J Gastroenterol. 2007;13(7):1060-6.

39. Behrens MD, Wagner WM, Krco CJ, Erskine CL, Kalli KR, Krempski J, Gad EA, Disis ML, Knutson KL. The endogenous danger signal, crystalline uric acid, signals for enhanced antibody immunity. Blood. 2008;111(3):1472-9.

40. Chen CJ, Shi Y, Hearn A, Fitzgerald K, Golenbock D, Reed G, Akira S, Rock KL. MyD88-dependent IL-1 receptor signaling is essential for gouty inflammation stimulated by monosodium urate crystals. J Clin Invest. 2006;116(8):2262-71.

41. Kato C, Sato K, Wakabayashi A, Eishi Y. The effects of allopurinol on immune function in normal BALB/c and SCID mice. Int J Immunopharmacol. 2000;22(7):54756.

42. Chocair P, Duley J, Simmonds HA, Cameron JS, Ianhez L, Arap S, Sabbaga E. Low-dose allopurinol plus azathioprine/cyclosporin/prednisolone, a novel immunosuppressive regimen. Lancet. 1993;342(8863):83-4.

43. Saglam F, Celik A, Sarioglu S, Cavdar C, Sifil A, Gulay H, Camsari T. Hyperuricemia influences chronic cyclosporine nephropathy. Transplant Proc. 2008;40(1):167-70.

44. Akalin E, Ganeshan SV, Winston J, Muntner P. Hyperuricemia is associated with the development of the composite outcomes of new cardiovascular events and chronic allograft nephropathy. Transplantation. 2008;86(5):652-8.

45. Kittleson MM, Bead V, Fradley M, St John ME, Champion HC, Kasper EK, Russell SD, Wittstein IS, Hare JM. Elevated uric acid levels predict allograft vasculopathy in cardiac transplant recipients. J Heart Lung Transplant. 2007;26(5):498-503.

46. Gores PF, Fryd DS, Sutherland DE, Najarian JS, Simmons RL. Hyperuricemia after renal transplantation. Am J Surg. 1988;156(5):397-400. 